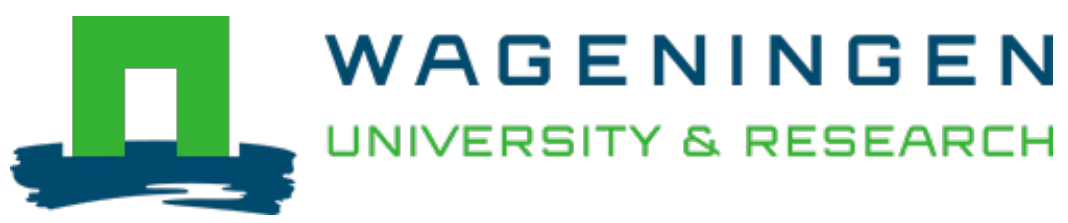

\title{
Deactivation of field cultivation in communal areas of South Africa: Patterns, drivers and socio-economic and ecological consequences
}

\author{
Land Use Policy \\ Shackleton, C.M.; Mograbi, P.J.; Drimie, S.; Fay, D.; Hebinck, P. et al \\ https://doi.org/10.1016/j.landusepol.2019.01.009
}

This article is made publicly available in the institutional repository of Wageningen University and Research, under the terms of article $25 \mathrm{fa}$ of the Dutch Copyright Act, also known as the Amendment Taverne. This has been done with explicit consent by the author.

Article 25 fa states that the author of a short scientific work funded either wholly or partially by Dutch public funds is entitled to make that work publicly available for no consideration following a reasonable period of time after the work was first published, provided that clear reference is made to the source of the first publication of the work.

This publication is distributed under The Association of Universities in the Netherlands (VSNU) 'Article $25 \mathrm{fa}$ implementation' project. In this project research outputs of researchers employed by Dutch Universities that comply with the legal requirements of Article $25 \mathrm{fa}$ of the Dutch Copyright Act are distributed online and free of cost or other barriers in institutional repositories. Research outputs are distributed six months after their first online publication in the original published version and with proper attribution to the source of the original publication.

You are permitted to download and use the publication for personal purposes. All rights remain with the author(s) and / or copyright owner(s) of this work. Any use of the publication or parts of it other than authorised under article $25 \mathrm{fa}$ of the Dutch Copyright act is prohibited. Wageningen University \& Research and the author(s) of this publication shall not be held responsible or liable for any damages resulting from your (re)use of this publication.

For questions regarding the public availability of this article please contact openscience.library@,wur.nl 


\title{
Deactivation of field cultivation in communal areas of South Africa: Patterns, drivers and socio-economic and ecological consequences
}

\author{
C.M. Shackleton ${ }^{\mathrm{a}, *}$, P.J. Mograbi ${ }^{\mathrm{a}}$, S. Drimie ${ }^{\mathrm{b}}$, D. Fay ${ }^{\mathrm{c}}$, P. Hebinck ${ }^{\mathrm{d}, \mathrm{e}}$, M.T. Hoffman ${ }^{\mathrm{f}}$, \\ K. Maciejewski ${ }^{\text {b }}$, W. Twine ${ }^{g}$
}

${ }^{\text {a }}$ Dept of Environmental Science, Rhodes University, Makhanda 6140, South Africa

${ }^{\mathrm{b}}$ The Southern Africa Food Lab, Centre for Complex Systems in Transition, University of Stellenbosch, Stellenbosch, South Africa

${ }^{\mathrm{c}}$ Dept of Anthropology, University of California Riverside, Riverside CA 92521, USA

${ }^{\mathrm{d}}$ Dept of Sociology of Development \& Change, Wageningen University, the Netherlands

${ }^{\mathrm{e}}$ Dept of Agricultural Economics \& Extension, University of Fort Hare, Alice, South Africa

${ }^{\mathrm{f}}$ Plant Conservation Unit, Dept of Biological Sciences, University of Cape Town, Private Bag X3, Rondebosch, 7701, South Africa

${ }^{\mathrm{g}}$ School of Animal, Plant and Environmental Sciences, University of the Witwatersrand, Wits 2050, South Africa

\section{A R T I C L E I N F O}

\section{Keywords:}

Communal

Field deactivation

Livelihoods

Local and national consequences

Patterns and drivers

South Africa

\begin{abstract}
A B S T R A C T
Smallholder production is a significant contributor to rural livelihoods and rural economies in much of the developing world. Yet, there is evidence of increasing disengagement in some regions, including southern Africa. However, there has been little consideration of the rates and the livelihood, ecological and policy implications of such. In this paper we examine previous studies on rates of deactivation of crop fields by smallholders in the communal areas of South Africa, supported by repeat photo images and case study material. Together these various methods show that it is a widespread phenomenon occurring at variable rates. Over short periods deactivation of crop fields can be balanced through some reactivation or intensification of homegardens. But over longer periods there is a net decline in the area of fields cultivated in many areas, with corresponding increases in the area of fallow land which, through time, may undergo changes towards more natural vegetation. We review the drivers of this deactivation of field cropping, and then contemplate the possible socio-economic and ecological implications at local and national scales. We show that there are numerous and profound implications that require greater understanding and policy responses.
\end{abstract}

\section{Introduction}

Increasing smallholder food productivity is considered essential to meeting the United Nations Sustainable Development Goals on poverty, food security and environmental sustainability (UNCTAD, 2015). However, many parts of sub-Saharan Africa have changed from being net exporters of food to net importers despite having vastly underrealised yields and enough arable land to increase cultivation fourfold (IFAD, 2009). Despite the importance of smallholders to global food production (Samberg et al., 2016), there has been a decline in smallholder field cultivation, both globally (Ramankutty and Foley, 1999; Cramer et al., 2008; Li and Li, 2017) and within southern Africa (Bryceson, 1996; Shackleton et al., 2013). However, a comprehensive understanding of the decline is confounded by the variation in the extent and rate of decline and in the drivers of this change, both within and between countries, but also across different spatio-temporal scales
(Rey Benayas et al., 2007; Pointereau et al., 2008; Munroe et al., 2013; Pereira and Navarro, 2015). Another difficulty lies in the problem of defining field abandonment or deactivation, largely because of the multiscale interconnectedness of the natural, economic and social aspects of smallholder agricultural activities and the broader livelihood systems in which it is embedded. Bryceson's (1996) concept of 'deagrarianisation', for example, describes a holistic process that constitutes changes in occupation, redirection of income-earning, social identification, and spatial relocation of rural inhabitants away from agricultural or subsistence production or rural livelihoods. This definition implies that agrarian lands are 'more than just fields' (sensu Hebinck et al., 2018), providing food and non-food goods, an income supplement, a safety net during adverse times or shocks, a sense of place, identity, and a home (Shackleton et al., 2001; Hebinck et al., 2018). A decline in field cultivation, therefore, reflects not only the changes in these spheres, but also has consequences for the land and the diversified

\footnotetext{
* Corresponding author.

E-mail address: c.shackleton@ru.ac.za (C.M. Shackleton).
} 
livelihood strategies of rural, smallholder farmers who comprise the largest and most vulnerable farming group through sub-Saharan Africa and much of southern Africa.

Approximately 2.5 million households in South Africa produce some food crops on less than 0.5 ha of land per household (Pienaar, 2013), meaning it rarely meets or exceeds subsistence levels (Cousins and Chikazunga, 2013). This group consitutes the largest group of cultivators in South Africa (Cousins and Chikazunga, 2013). Most of these smallholders reside in the former 'homelands' (areas to which black South Africans were relocated during the racially discriminatory 'Apartheid' era) and $61 \%$ of them are dependent to some degree on government welfare grants (Pienaar, 2013). This group produces little to no surplus crops for sale, but their produce is an important supplement for household food requirements and diversity (Pienaar, 2013). Despite the important role of field cultivation in their livelihood strategies, identity, nutritional needs and diversity, several studies in the former homelands, across various locations, time scales and methods, have indicated a progressive pattern of decline in the area of active fields and an increase in the area of seemingly disused fields (e.g. Shackleton et al., 2013; de la Hey and Beinart, 2017; Blair et al.,2018; Hebinck et al., 2018), with largely unexplored implications for the households and communities involved, or at higher scales and policy options.

Within the context of the above, the objective of this paper is to assess the decline in field agriculture in the South African communal areas and to identify and discuss its implications across ecological, social and economic spheres at both local and national scales. We first explore the national policy context in relation to agriculture in the communal areas. Then we review what is known of the rates of decline in field cropping in South Africa's communal areas and profile three case studies that document the context-specific drivers of disengagement from crop farming. We then synthesise what is known about the main drivers of field decline in South African communal lands. Finally, we explore the possible consequences of these changes for social, economic and ecological systems.

\section{Current national policy framings of arable production in communal areas of South Africa}

In 2002, the Department of Agriculture, Fisheries and Forestry (DAFF) released the Integrated Food Security Strategy (IFSS), which set out "to overcome rural food insecurity by increasing the participation of food insecure households in productive agriculture sector activities" (2002, p. 28). This strategy frames government support and programmes in communal areas, which try to nudge smallholder growers away from subsistence farming towards selling their produce on local markets. Two recent flagship initiatives have been the Ilima/Letsema and the Fetsa Tlala (End Hunger) campaigns, both of which have focused on production inputs. Fetsa Tlala, for example, encouraged communal land farmers, through the provision of mechanisation, distribution centres, advisory services and access to markets, to produce yellow maize and dry beans for the market. Households would then use the income generated to purchase food. More recently, this initiative focused on attaining one million hectares under production by 2018/ 19 , with a primary focus on maize, beans and potatoes, which are considered important contributors to households' basic dietary requirements (DAFF, 2015).

However, neither the IFSS strategy nor the subsequent action plan (DAFF, 2015) was well grounded in the reality of current farming perspectives and dynamics in the communal areas of South Africa. First, only a very small proportion of households in the communal areas produce sufficient food to offer any to the market (Cousins and Chikazunga, 2013). Second, the latent expectation of turning smallholder and subsistence farmers into commercial farmers has been expensive and largely ineffective (Aliber and Hall, 2012; Aliber and Cousins, 2013; Greenberg, 2013; Cousins, 2014; Aliber, 2015). For example, in the Eastern Cape, poor households were unable to pay the $\mathrm{R} 1,800$ commitment fee required to participate in the Fetsa Tlala progrm (Aliber, 2015; Herd-Hoare, 2018). Results from the 2015 national General Household Survey support this finding and show that only $12 \%$ of households engaged in agriculture received government services in 2014 while only $2 \%$ received training (Aliber, 2015). Nonetheless, there have also been some localised successes such as the Siyazondla program in the Eastern Cape. Even though it has subsequently been cancelled, this successful programme focused on networking through social learning to build intensified homegarden cultivation at smaller, closer sites rather than larger and distant fields (Fay, 2013).

A third concern over the IFSS is that the larger scale dynamics of changing demographics, lifestyles and urbanisation, which under some circumstances can lead to a deactivation from agriculture (Shackleton and Luckert, 2015; de la Hey and Beinart, 2017; Hebinck et al., 2018), do not appear to have been factored into the initial design. Thus, increasing links with and experiences of urban services, conveniences, consumption patterns and lifestyles influence how rural people view their own lifestyles and contribute to shaping the choices of how they wish to make a living. Fourth, the policy does not recognise the diversity of other values and uses of land in communal areas. For example, what appears to be fallow or unused land may not be so since it is used for grazing, collection of natural resources and cultural and spiritual needs (Hebinck et al., 2018). Nor does the policy recognise the widespread practices of intercropping rather than single crop production (Shackleton et al., 2001). Finally, there appears to be little appreciation of the multi-functionality of rural livelihoods, and the social differentiation of who engages in particular livelihood activities and why (Hebinck and Cousins, 2013). Deeper understandings of these realities would help to identify interventions and support that different groupings may benefit from to improve their livelihoods and reduce vulnerabilities.

Broader, intersectoral policy frameworks such as the National Development Plan (RSA 2012) recognise that for agriculture to catalyse the rural economy, it would need to be developed within a comprehensive approach to rural development. This means planning interventions in conjunction with land reform, basic service delivery, rural human settlement development, improved access to education and healthcare, and small enterprise development. Yet despite these statements, there is little evidence of the design of support programmes based on an understanding of the underlying dynamics in communal areas.

\section{Local level studies examining declines in field area in South Africa}

There have been several local level studies in South Africa over the last two decades that have reported a decline in field cultivation (Table 1). Most studies are from the Ciskei and Transkei, which are both former homelands in the Eastern Cape province (Table 1; Fig. 1) A similar decline in cultivation has also been reported within several land restitution sites in Limpopo Province (McCusker, 2004) and within an urban commonage site in the Eastern Cape (Stickler and Shackleton, 2015). The majority of assessments are based on a time series analysis of aerial photographs, although several studies also used household interviews, oral histories and other qualitative approaches. A majority of these assessments suggest that there has been a decline in the area of fields under crops. In some regions, however, the decline in fields has been replaced by a more intensive cultivation of small homegardens (Andrew and Fox, 2004; Fay, 2009). The rate of change varied in the quantitative analyses, as did the period of peak deactivation. The absolute values of the percentage annual change are relatively low ( $<-0.5 \%$ p.a.) primarily because the total area of land in the landscape under fields is also typically low $(<15 \%)$.

A novel approach in the analyses of long-term environmental 


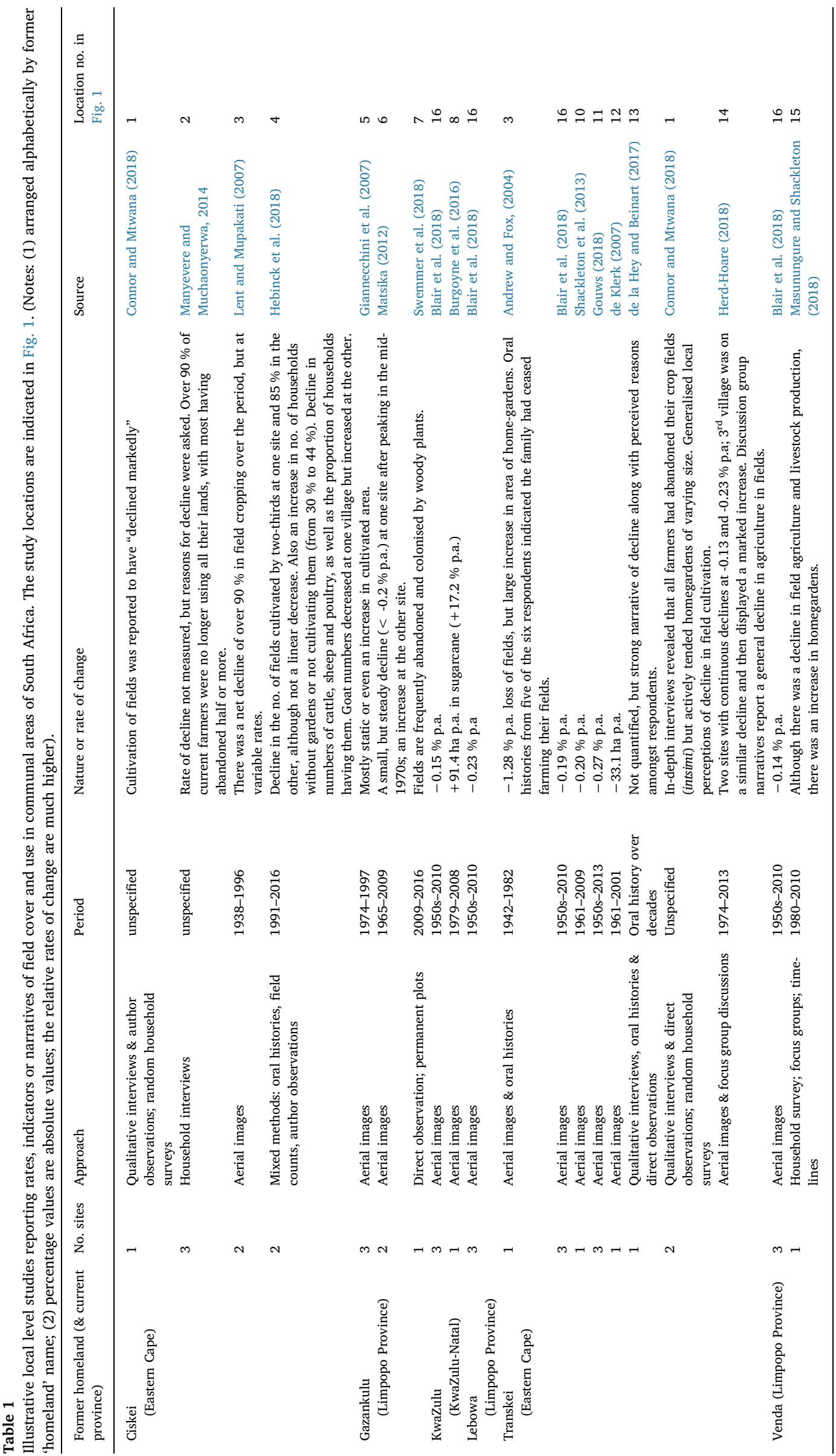



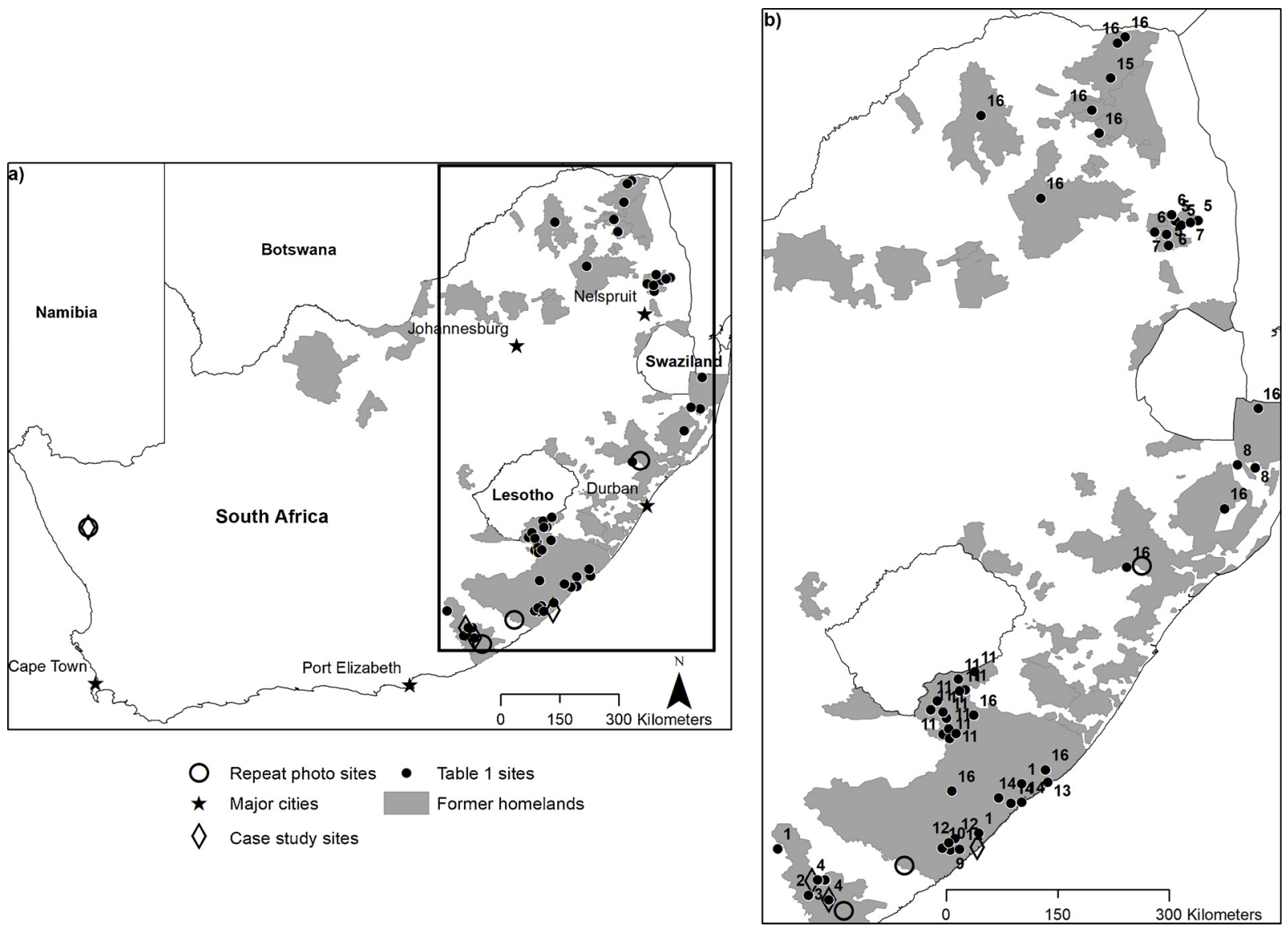

Fig. 1. Location of previous studies on land use change in former 'homeland', communal areas of South Africa (see Table 1 and text for details).

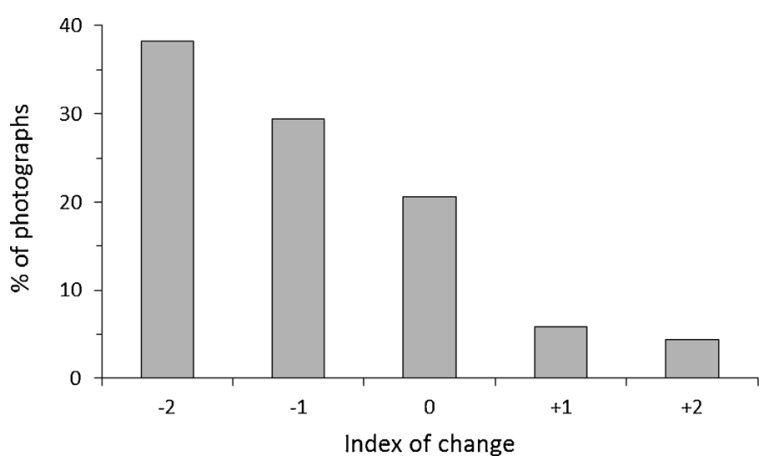

Fig. 2. The percentage of photo-pairs $(n=67)$ located in the communal areas of the Northern Cape, Eastern Cape (the former Ciskei and Transkei regions) and KwaZulu-Natal provinces in which the change in the area of cultivated fields was rated on a five-point scale $(-2=$ the cultivated area in the most recent photograph has declined by more than $25 \%$ of the area observed in original photograph; $-1=$ the cultivated area has declined by between $5-25 \%$; $0=$ little observable change with an error margin of $-5 \%$ to $+5 \% ;+1=$ the cultivated area had increased by between $5-25 \% ;+2=$ the cultivated area has increased by more than $25 \%$ ).

change in South Africa is the use of repeat photographs (Masubelele et al., 2015; Stevens et al., 2015). We searched a database maintained by the Plant Conservation Unit, University of Cape Town, of 2000 photographs to locate those (1) from communal areas and (2) in which the original photograph showed areas of cultivation. This yielded 67 returns. The median date for the original photographs was 1947 and all but one was taken before 1970 . We then evaluated the extent of change in the area of cultivated fields in the more recent, repeat photograph according to a five-point scale described in the caption to Fig. 2. Results indicate that at more than two-thirds of the sites, the area of cultivation had declined between the time of the original photograph and the later, repeat photograph. For more than one-third of the photo pairs the decline was greater than $25 \%$ of the original area. One-fifth of the sites showed little change, while at only seven $(10 \%)$ of the 67 sites was there evidence of an increase in the area of cultivated fields. Examples of these significant declines in the area of cultivated fields are shown in Fig. 3.

In addition to the analyses of aerial and ground photos, three case studies illustrate the complexity and dynamic nature of field deactivation. These studies span an aridity gradient from arid (Namaqualand) to relatively moist (Transkei Wild Coast), with a corresponding increase in suitability for rain-fed arable farming (see Fig. 1 for locations).

\subsection{Paulshoek, Namaqualand}

Paulshoek is a relatively small village of about 100 households $\left(30^{\circ} 25^{\prime} \mathrm{S} ; 18^{\circ} 15^{\prime} \mathrm{E}\right)$ in the Leliefontein communal area of Namaqualand (Rohde and Hoffman, 2008). The region receives less than $200 \mathrm{~mm}$ of rain per year, mostly in winter. The roughly 20,000 ha of village commons are used primarily for grazing sheep and goats. The cultivation of field crops is still undertaken by some households depending on the amount of rain at the start of winter (April-June). Nowadays the grains produced contribute to the grazing reserves for their livestock during the dry summer months and frequent droughts.

During the first half of the $20^{\text {th }}$ century, individual households were significantly more dependent on the cultivation of wheat, oats, barley and rye for their nutritional needs and for supplementary feed for their herds (Rohde and Hoffman, 2008). Historically, extended family units occupied different parts of the commons which was divided into separate areas determined primarily by the location of viable cropland 

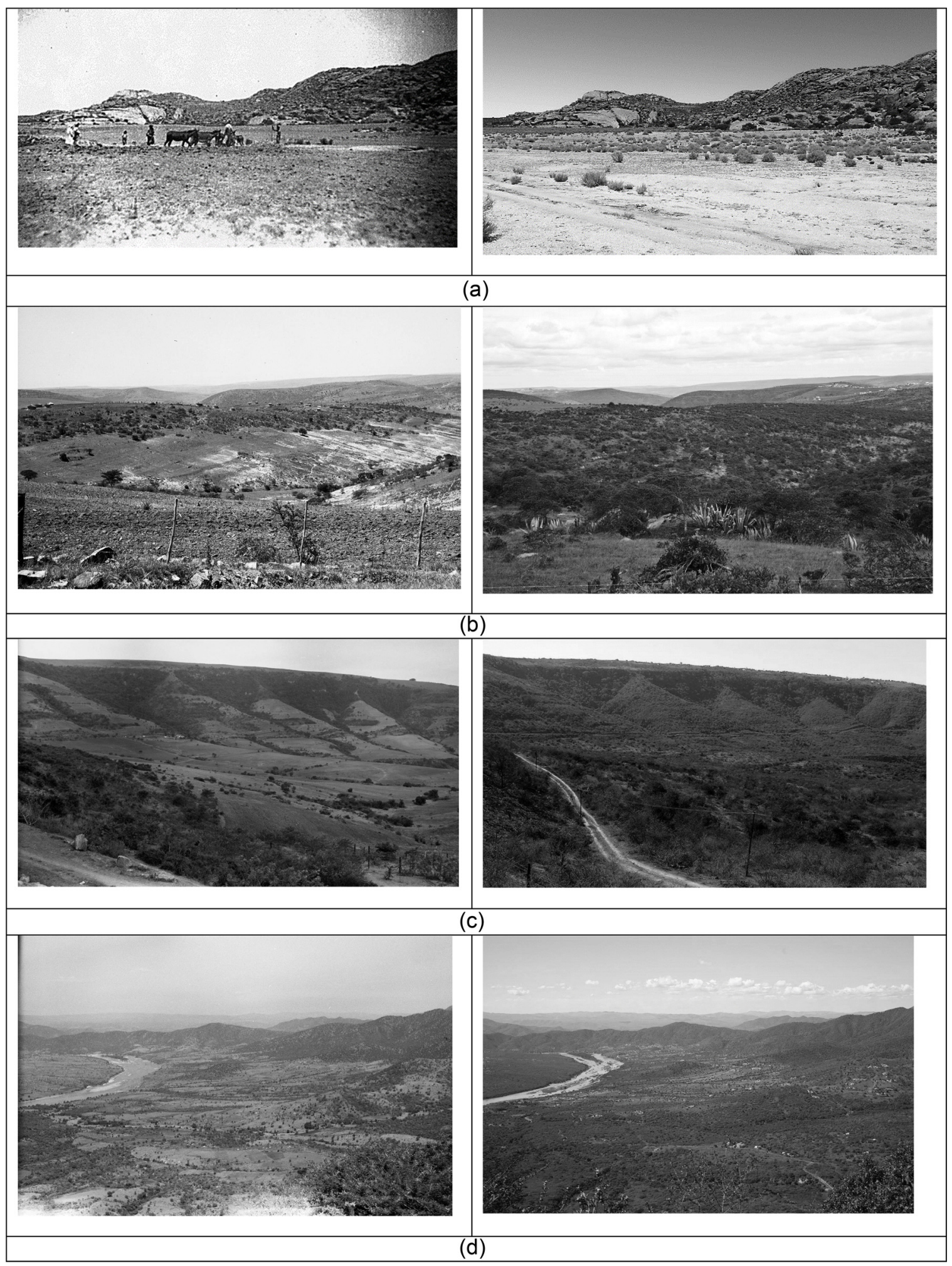

Fig. 3. (a) Threshing of the wheat after the harvest in Paulshoek, Namaqualand. Original photograph (left) by Andrews (1938) and repeat (right) by Rohde (8 Nov 2005) showing an increase of the semi-toxic, woody shrub, Galenia africana after field deactivation (No. 124).

(b) Eroded fields in Gawukeni Location (former Ciskei) photographed by Comins in 1956, which after deactivation were encroached by woody shrubs (photographed by Puttick on 25 Jan 2011 (No. 612)).

(c) Extensive fields at Eagle-Siding just north of the Kei River photographed by Edwards in 1954, which by 13 August 2010 (photographed by Puttick and Hoffman) had been deactivated and covered in woody plants, especially Vachellia karroo (No. 548).

(d) Widespread cultivation of the low-lying areas at Tugela Rand in KwaZulu-Natal photographed by Edwards in 1957, which showed signs of deactivation and significant woody plant encroachment when photographed by Puttick on 12 April 2011 (No. 639). (See Fig. 1 for map locations). 


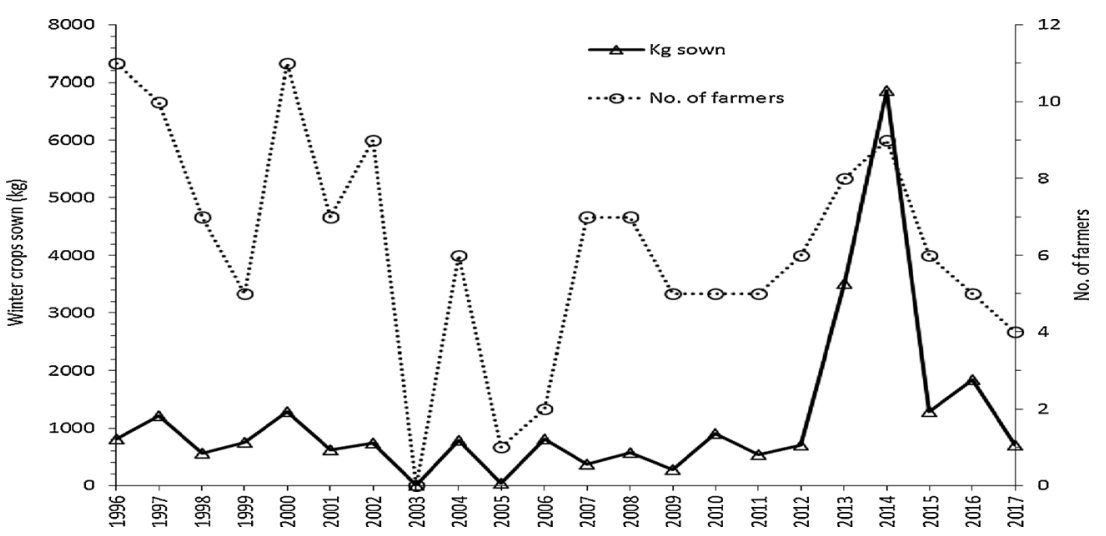

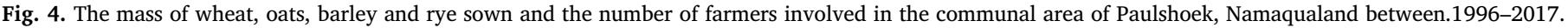

sites or 'saaipersele'. During the second half of the $20^{\text {th }}$ century Paulshoek residents moved away from these relatively remote sites and became increasingly concentrated in the main village. As a result, households became less dependent on agrarian activities for their livelihoods and more involved in the wage economy of the mines and state-owned enterprises. However, even today, family units maintain satellite stockposts in the outer commons which are often established in close proximity to their historical cropping sites at least for some part of the year.

Cropland sites are not owned by residents but are rented from the Khamiesberg municipality on an annual basis. There are currently 40 registered cropland sites rented by 28 residents, ranging in size from three to 71 ha with an average size of 32 ha. Since 1996, when detailed data on cropping were first recorded in the village, the number of farmers who have cultivated their cropland sites has ranged from none to 11 with an average of six individuals (Fig. 4). Between 1996 and 2012 the average weight of seed sown was less than $650 \mathrm{~kg}$. This increased by an order of magnitude in 2014 primarily because of a single individual who expanded his livestock and cropland site holdings with a view to becoming a commercial farmer.

The ratio of mass of seeds sown to kilograms harvested is strongly dependent on rainfall $\left(\mathrm{y}=0.0477 \mathrm{x}-2.0105 ; \mathrm{R}^{2}=0.4476 ; \mathrm{n}=22\right.$; $\mathrm{p}<0.001$ ) and has ranged from zero to 14 (Fig. 5) with complete crop failure occurring in six of the 21 years when crops were sown (1998, 2005, 2010, 2014, 2016 and 2017). Because of the risk associated with crop cultivation in this arid environment it is unlikely to expand, although one or two aspirant farmers clearly still see its value in providing forage for their herds. Yet, for the majority there has been a gradual, yet discernible, move away from cultivation (Rohde and Hoffman, 2008).

\subsection{Guquka and Koloni, central Eastern Cape}

Two villages, Guquka and Koloni, have been intensively studied over the last 25 years and a detailed picture has been developed around land, resource use and local livelihoods (Hebinck and Lent, 2007). The data include interviews, life histories, observations, field measurements, archival data, field cropping measures, livestock and resource and crop harvesting (Hebinck and Lent, 2007). Guquka (32 39' S; $26^{\circ}$ 56 ' E; 840 m.a.s.l.) is situated close to Hogsback while Koloni (32 ${ }^{\circ} 53^{\prime}$ S; $27^{\circ} 05^{\prime} \mathrm{E} ; 680$ m.a.sl.) is between Middledrift and Dimbaza. Both villages originate from settlement processes during the frontier wars with Guquka established in 1899 and Koloni in 1874. Land was allocated for crops as arable allotments of about $3-4$ morgen $(1$ morgen $=0.856$ ha), land for residential purposes, and the remainder was designated as 'commonage' for communal grazing and gathering.

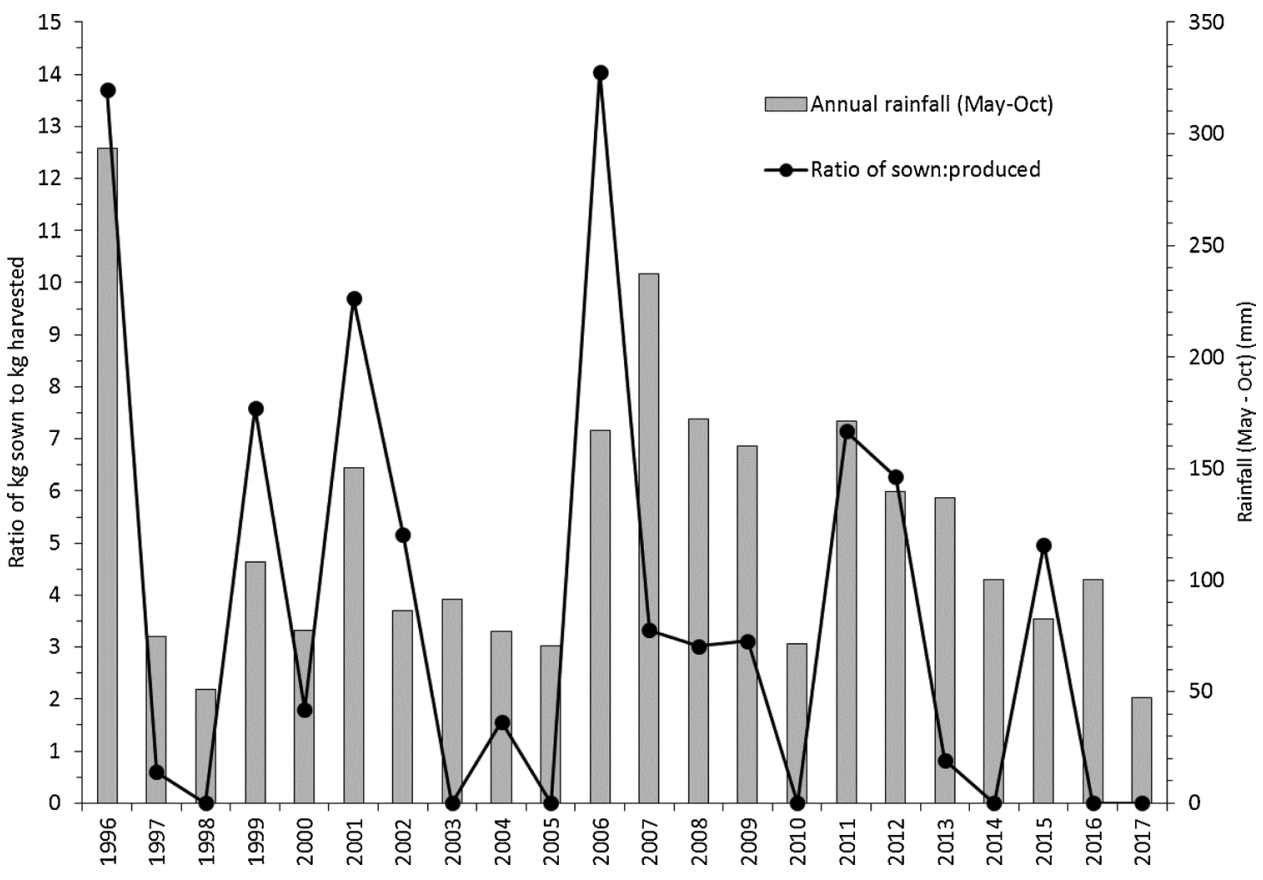

Fig. 5. The ratio of the mass of seed sown to the mass produced and rainfall over the period 1996-2017 in Paulshoek. 


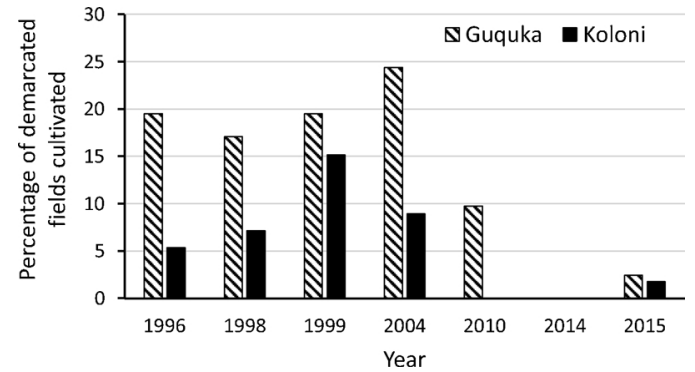

Fig. 6. The proportion of fields cultivated in Guquka and Koloni for different years between 1996 and 2015 (redrawn from Hebinck et al., 2018).

The oral histories convey that field cultivation and labour migrancy interacted well. Migrant wages provided the monetary and labour resources to expand and continue field cultivation. This lasted from about 1900 until about 1930-1940. From then on, field cultivation gradually declined. Migrant contracts also changed from about 4-6 months to more permanent contracts. As a result the time spent at home over the Christmas holiday period was used more for social and cultural activities that competed for time with cultivation (Hebinck and Smith, 2007). The lack of labour and over time, the aging of landholders, not only mirrors the transformation of the rural economy and livelihoods but also explains the gradual decline in field cultivation. When one gets older, "one loses the power to work". "Not being able to plough" means that labour and land as well as the ability to access the means to 'plough' are not available. When alternative sources of labour (family or hired) and capital are limited or unaffordable, then the cultivation of fields, the buying of seed, insecticides, fertiliser or manure and the fencing of fields declines. Currently most arable fields are fallow (Fig. 6) and used for cattle grazing and foraging of medicinal plants, edible herbs and firewood. Although the use of some fields for crops increases when migrants return home to reinvigorate field cultivation, the general longer-term decline in the total area cultivated is readily apparent.

Despite the decline in field cropping, some, but not all, households maintain a homegarden largely for domestic purposes (Hebinck et al., 2018). Only a few actively market any crops. Homegardening is, as people say, "to save money", which is indicative that most villagers have become food purchasers, paying for their food from a combination of remittances and government social grants.

\subsection{Dwesa-Cwebe, Wild Coast, Eastern Cape}

The communities on either side of the Mbhashe River, around Dwesa-Cwebe Nature Reserve ( $32^{\circ} 18^{\prime} \mathrm{S}$; $\left.28^{\circ} 55^{\prime} \mathrm{E}\right)$, have been the site of panel-sample household surveys and qualitative research at regular intervals between 1998 and 2015 (e.g. Fay, 2009; Fay and Palmer, 2002; Tavenner, 2016; Timmermans, 2004). In 1998, these revealed clear differences which showed that rain-fed field cultivation was hardly practiced on the Dwesa side, while it was still widespread amongst the Cwebe communities. Aerial photographic analysis of the Dwesa side showed that most field cultivation had generally ceased between 1962 and 1981. Residents of the Dwesa communities cited many reasons for giving up field cultivation, including lack of fencing, damage by livestock and wild animals, drought, declining soil fertility, and lack of labour (Timmermans, 2004).

On the Cwebe side, however, field cultivation was still common in the late 1990s. Fields on the flood plains of the Mbhashe and Ntlonyane rivers are relatively productive, and complement homegardens in their response to rainfall extremes. There was less absenteeism of women and children for employment and education relative to the Dwesa side, which meant greater availability of labour for cultivation. Traction and labour remained highly mobile through ploughing companies and work parties, which were essential to successful maize cultivation (Fay, 2003).
The 2003, 2009 and 2015 surveys in Cwebe communities, however, revealed declines in field cultivation from around $77 \%$ of panel sample households in 1998 to $22-24 \%$ in the later years. One cause was the spatial change in settlement patterns. For example, when betterment villagisation was implemented in the Cwebe communities in the 1980s, most households were relocated to new homestead sites, and their former residential or garden sites were abandoned or converted to arable fields. However, post the democratic transition in the mid-1990s, some returned to their pre-betterment sites. In doing so, they converted the post-betterment fields back to homesteads with gardens. This rendered the adjoining fields more vulnerable to livestock damage because the homesteads and fields were more isolated from one another and therefore harder for neighbours to watch out for one another's fields.

A second reason for the decline in cultivation in Cwebe is related to the restructuring of the mining industry's labour practices in the early 2000s. This undermined longstanding male migration patterns, and more women and families have therefore left the area in search of work. At the same time, Child Support Grants (CSGs) from the national government became increasingly important locally, with large increases in school enrolment related to improved facilities and transport. This, in turn, withdrew boys from their traditional herding responsibilities and from guarding fields. By 2003, nearly half of households in Cwebe had a CSG, as did about $60 \%$ in Hobeni in 2009 and 2015. In the 2009 survey the number of CSGs a household received was weakly correlated with the absence of field cultivation $(r=-0.26, \mathrm{p}<0.05)$. People also recount purchasing maize and other staples with grants rather than through cultivation.

Collective labour and ploughing arrangements also declined. Oxdrawn ploughing remains important, but declined from 88\% (1998) and $85 \%$ (2009) to around $51 \%$, while the hiring of tractors increased from zero to $12 \%$ in 2015 . This shift also has to be seen against the reduction of state support for cattle dipping in the Eastern Cape and its consequences for ploughing (Brown et al., 2013). For example, in 2009, over $60 \%$ of cattle owners reported that their animals' health and numbers had declined greatly. This scenario is also reported by Shackleton et al. (2013) about $30 \mathrm{~km}$ to the southwest. Communal work parties have declined, even among those who cultivate in fields (Fig. 7).

Despite the drop in field cultivation, some Hobeni residents have not abandoned agriculture. When the trajectories of crop cultivation are disaggregated at the individual household level then a trend emerges which might be better characterised as "deactivation" and "reactivation" of fields rather than as simply "abandonment" (sensu Shackleton and Hebinck, 2018). For example, in 2009, 18 (of $N=80$ ) households practiced field cultivation, but in 2015, 13 of these households had stopped this practice. However, there were still 18 households cultivating in 2015. This was because 12 other households had "reactivated" fields that they had been cultivating in 1998 but which they had "deactivated" by 2009 , together with one household that began cultivating for the first time in 2015. In this area, and contrary to a more general perception of "communal tenure", land does not revert to the headman

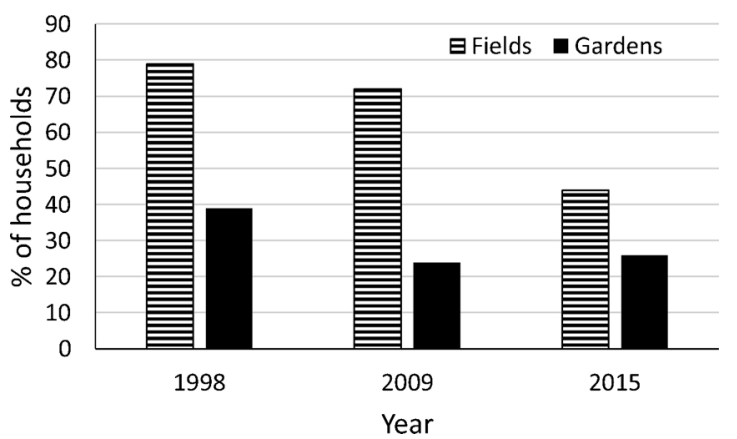

Fig. 7. The proportion of households holding agricultural work parties in Hobeni (1998 and 20,09 presented in Fay (2013)). 


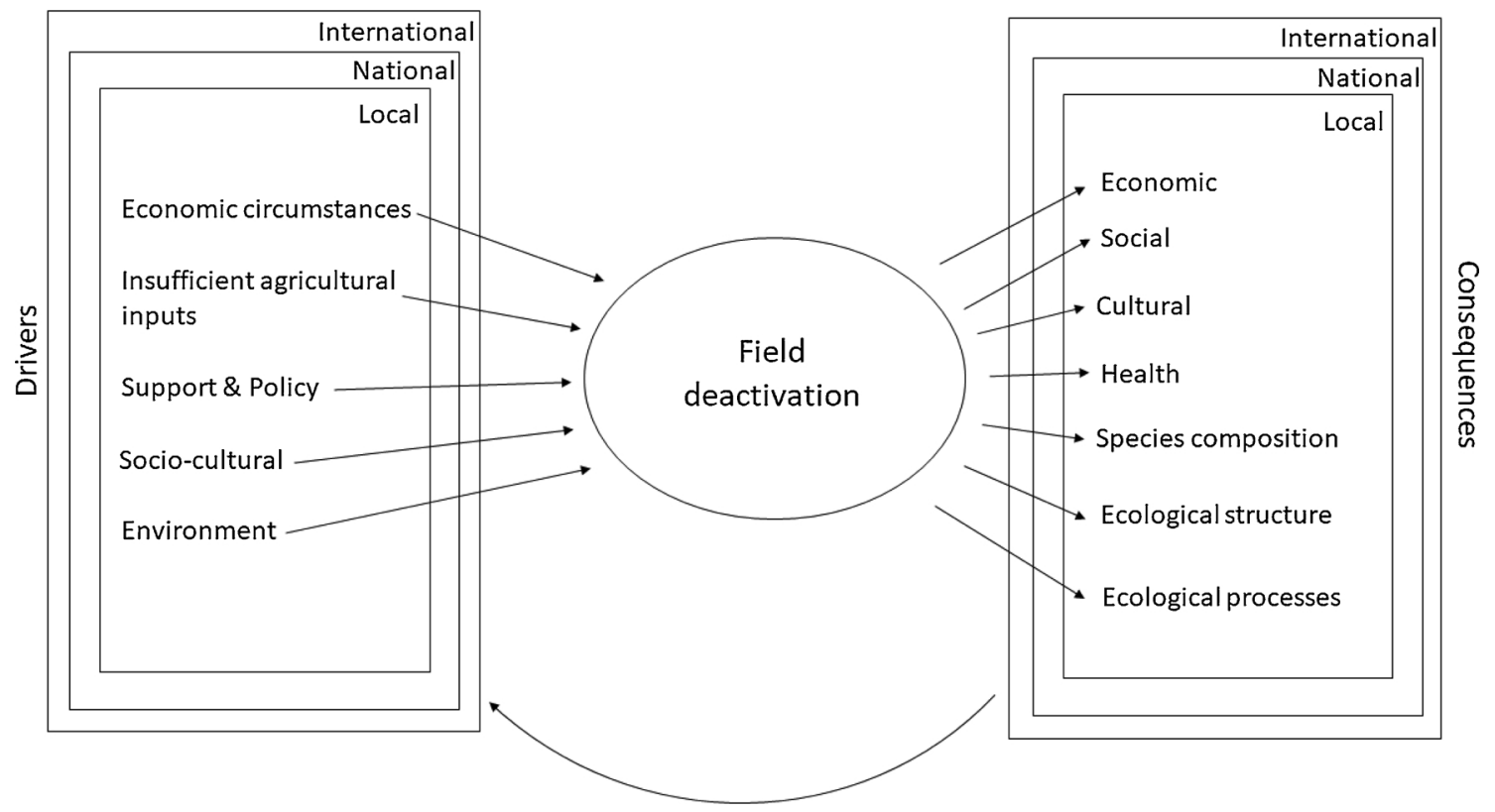

Fig. 8. Local level drivers and consequences of field deactivation, nested within higher scale ones.

for reallocation when left uncultivated. The long-term sustainability of this documented "deactivation" and "reactivation" practice, however, is uncertain. Households that have continued or resumed field cultivation are all older, longer-established households, and dense bush encroachment may limit reactivation in the future. However, field cultivation clearly remains part of a repertoire of potential livelihood strategies in the medium term. In addition, homegarden cultivation has intensified, with diversification of vegetables and increased planting of fruit trees. This has occurred partly as a result of the assistance and networking provided through the Siyazondla programme, although direct support for this programme ended in 2011 (Fay, 2013). Homegardens are generally smaller and easier to fence than larger, distant fields, and it is easier to integrate homegarden work with other domestic tasks, and guard against livestock incursions.

In summary, these three cases show that even across very different ecological, cultural and economic settings, the local level uses of land is in constant flux as rural people respond to opportunities and adversities at many different levels. They also reveal that while the net trajectory at village level may be a decline in the area cultivated the process is neither linear nor inevitable. The trajectory of change is often interrupted by periods of reactivation of some fields or even creation of new fields if there are sufficient resources and inclination within specific households. Many households, especially in the moister regions, have also retained or even expanded the cultivation of 'gardens' close to the homestead. These gardens provide vital dietary diversity and health benefits. However, since most are considerably smaller than crop fields, there is a net increase in the area of land at village or community scale that is now under other land uses (such as grazing) and providing other benefit flows (such as gathered products rather than crops). Typically, with time, these deactivated, former fields become dominated by scrubby woody herbs and shrubs or trees, but the rate and nature is subject to local fire frequencies, harvesting practices and browsing pressures and shaped by climatic and edaphic characteristics. Lastly, there is a complex interplay of local and wider-scale drivers of deactivation, specific to each site, but also with some commonalities. These include the changing nature of migrancy and labour availability, villagisation, government social grants and an increasingly cash-based economy. They also include the changing availability of livestock, which provide not only draught power and manure, but also raid fields and destroy crops if they are not fenced or the animals are not closely herded.
These findings from local level studies differ from those undertaken over larger areas of South Africa using remote sensing applications. For example, Jewitt et al. (2015) using satellite imagery to examine land cover change in KwaZulu-Natal province between 2005 and 2011 reported a $21 \%$ p.a. increase in cultivated area in the communal areas. While several explanations for these differences are possible, the discrepancy that exists in the findings from small- and large-scale studies, concerning the change in area of cultivated fields in communal areas, has not been satisfactorily resolved. Not only does the level of detail differ between different studies but so too does the time-frame of observation. The change in area cultivated, derived from short-term studies of only a few years (e.g. Jewitt et al., 2015) may be different from the results derived from studies spanning decades. The findings might also be different at larger scales because of the inclusion in the analysis of land restitution projects, corporate farming programs and externally supported, smallholder agricultural projects. Such projects often result in the aggregation of farming areas that span hundreds of hectares.

\section{Drivers of field deactivation in communal areas}

Internationally a range of socio-economic and ecological drivers of smallholder arable field decline have been identified (Benayas et al., 2007; Munroe et al., 2013). Socio-economic factors tend to be more important than environmental (Benayas et al., 2007), but the particular set of drivers and their effects are site-specific, and are strongly influenced by the social and historical context (Beilin et al., 2014).

In South Africa, literature from the Eastern Cape (where most of the studies have been done), reveals a diverse and inter-connected set of local level drivers, as perceived by local communities (rather than by external researchers). We classify these local level drivers into five broad themes: 1) economic context, 2) insufficient inputs, 3) support and policy, 4) socio-cultural change, and 5) environmental (Fig. 8). However, there are no clear boundaries between these categories as some drivers span these divisions. For example, a lack of labour may result from an inability to pay for hired labourers (input constraints), a lack of available labourers as a result of rural outmigration (changing livelihoods), and/or young labourers may refuse patriarchal expectation to work in the fields as they perceive farming to be an old-fashioned pursuit (societal change). We limit our focus here to local-level drivers, recognising that they are, in turn, influenced by drivers at global (e.g. climate change, globalisation, urbanisation) and national 
(e.g. government policy, politics, macro-economy) scales (Lambin et al., 2001). Similarly, local consequences may affect global socio-economic and ecological processes, particularly as a deactivation of productive fields in one location may potentially displace land use effects to a different geographic location, where new fields are being cleared and cultivated to support the food export market (Meyfroidt et al., 2013).

\subsection{Economic circumstances}

Income from non-agricultural sources, such as remittances from migrant household members, is now a prominent feature of rural livelihoods across sub-Saharan Africa (Bryceson, 1996). In South Africa, government social grants have also become an important source of cash income for millions of households (Hebinck and van Averbeke, 2007). This increased access to non-farm cash is associated with reduced household dependence on fields as a source of supplementary income or home-grown food (de Klerk, 2007; Shackleton et al., 2013; Fay, 2015; de la Hey and Beinart, 2017; Ncube et al., 2017). This is particularly so in contexts where store-bought food has become more easily accessible with improvements in road infrastructure and development of rural towns (de Klerk, 2007; Pereira et al., 2014). Out-migration to urban areas, particularly by the youth in search of employment, is seen by many elders in rural villages as a major constraint to the availability of local labour (Manyevere and Muchaonyerwa, 2014; Fay, 2015; de la Hey and Beinart, 2017; Ncube et al., 2017).

\subsection{Insufficient agricultural inputs}

Lack of adequate access to agricultural inputs, either due to unavailability or prohibitive costs, is often reported by local villagers in South Africa as a major constraint to field cultivation (Andrew and Fox, 2004; Shackleton et al., 2013; Manyevere and Muchaonyerwa, 2014; Fay, 2015; de la Hey and Beinart, 2017; Ncube et al., 2017; Connor and Mtwana, 2018). These inputs include traction (oxen or tractors), labour, fencing, fertiliser, expertise, and access to credit. The unavailability of traction is often ascribed to long-term declines in the number of oxen for ploughing after reduction in government support of animal health programmes (Shackleton et al., 2013). These costs, along with low or declining crop yields, result in unattractive returns on investment of time, effort and money (Shackleton et al., 2013; Hebinck et al., 2018). There is little evidence of social grant incomes being invested into agriculture, further suggesting that the returns on agricultural investment do not match households' expectations and consequently social grant income is used largely used to cover household needs (Gutura and Tanga, 2017).

\subsection{Government support and policy constraints}

Although South African government policy is focused on "agricultural development", this rhetoric is distant from the lived experience of most rural dwellers. A lack of practical government support has been mentioned as a constraint in some communities (Ncube et al. 2017). Large, top-down imposed government projects (e.g. Siyakhula/Massive Food Programme) have yielded short-term production increases in some places, but no long-lived sustainability or post-project support (de la Hey and Beinart, 2017). Voiced support includes access to tractors, seed and fertiliser (Shackleton et al., 2013).

\subsection{Socio-cultural change}

Changes in the ability, need, or desire to engage in field cultivation, are themselves influenced by broader socio-cultural changes underway in rural societies. The pervasive processes of modernisation and urbanisation influence values, perceptions and aspirations in relation to the agrarian way of life. Rural community members, particularly elders, lament the lack of interest by the youth in farming, often referring to them as "lazy" (Shackleton et al., 2013; Manyevere and Muchaonyerwa, 2014; Trefry et al., 2014; de la Hey and Beinart, 2017). This is ascribed to factors such as the lure of modernity, and the perception that farming is an activity of the elderly and the poor (Manyevere and Muchaonyerwa, 2014; de la Hey and Beinart, 2017). A decline in patriarchy, itself influenced by a long history of male migrant labour, has resulted in a "loss of control" of household labour, of both the youth and females, by the male head (de la Hey and Beinart, 2017). Improved access to schooling has also reduced the time that young boys have available to herd cattle to keep them out of fields or to chase monkeys and birds from fields (de Klerk, 2007; Andrew and Fox, 2004; de la Hey and Beinart, 2017). The lack of interest and participation in agriculture result in the loss of agricultural knowledge and skills, acting as a further barrier to inter-generational continuity (Manyevere and Muchaonyerwa, 2014; Connor and Mtwana, 2018). Concern about theft and security as an additional disincentive to cultivation highlights the role of changing social relations within rural communities (Manyevere and Muchaonyerwa, 2014; Connor and Mtwana, 2018).

\subsection{Environmental factors}

The effects of socio-economic drivers are often exacerbated by environmental ones. Key amongst these are perceived weather-related challenges such as changing rainfall patterns and rising temperatures (Manyevere and Muchaonyerwa, 2014; Ncube et al., 2017). Soil degradation, both in terms of declining soil fertility and increasing erosion, is another factor that some respondents invoke to explain their disengagement from field cropping (Andrew and Fox, 2004; Shackleton et al., 2013; Manyevere and Muchaonyerwa, 2014; Connor and Mtwana, 2018). Finally, increasing crop losses due to livestock, wild animals, pests, and diseases, is cited by many as a major disincentive against field cropping (Andrew and Fox, 2004; Shackleton et al., 2013; Manyevere and Muchaonyerwa, 2014; Fay, 2015; de la Hey and Beinart, 2017; Connor and Mtwana, 2018; Herd-Hoare, 2018). A declining area also increases the intensity of crop pests such as birds, monkey or bushpigs in the remaining fields (Herd-Hoare, 2018), which illustrates but one implication of field deactivation. Change in land use, such as village expansion and the conversion of arable land into residential stands, is an additional factor in some contexts (Fay, 2015).

\section{Implications and consequences of the decline in area of field cultivation}

There is little doubt that field deactivation has important consequences for the households involved as well as for local communities and regional economies if it is widespread (Fig. 8). Here we discuss the consequences and implications of field deactivation in the communal lands of South Africa by applying a complexity lens and using a systems approach. We have generated seven categories which we have divided into socio-economic (Table 2) and ecological (Table 3). However, there are feedbacks and dependencies between these domains and consequently they should not be read in isolation.

\subsection{Socio-economic consequences and implications of field deactivation}

\subsubsection{Economic}

The potential changes in the household and local economy because of a decline in field cultivation are highly context specific. Any changes will be shaped by the nature of local livelihoods, the extent and type of agriculture and links to markets, both to sell agricultural produce, but also to purchase agricultural inputs or food. At the household level, the deactivation of fields will free up the labour that used to work the fields for household or other activities. Whether this will lead to an improvement in the household economy or not will depend on the nature of the other opportunities in which the labour can engage. However, with very high unemployment in the former homeland areas of South 
Table 2

Implications of a decline in the area used for field cultivation for local and national level social and economic patterns and processes.

\begin{tabular}{|c|c|c|}
\hline Implication & Local & Regional/National \\
\hline \multicolumn{3}{|l|}{ Economic } \\
\hline Income & $\begin{array}{l}\text { Loss of agricultural contribution to income (however minor), altered income } \\
\text { diversification. Alternately, more free time may allow for investment in other } \\
\text { opportunities. In highly variable environments, scarce cash that used to be invested } \\
\text { in agriculture may be invested in other economic activities and purchases of food. }\end{array}$ & Increased dependence on government and other support networks. \\
\hline Agricultural economy & Diminishment of agricultural inputs, processing, and outputs. & Reduction of agricultural-based economy. \\
\hline Unemployment & $\begin{array}{l}\text { Less labour required to work fields and associated agricultural activities and local } \\
\text { chains; reduced agricultural employment opportunities. Such labour may engage in } \\
\text { other sectors. }\end{array}$ & $\begin{array}{l}\text { Increased pool of unemployed workers, esp. youth, many of whom } \\
\text { will likely move to urban areas. }\end{array}$ \\
\hline Skills and expertise & $\begin{array}{l}\text { Reduced transmission and application of knowledge and skills in subsistence and } \\
\text { small-scale commercial food production systems. }\end{array}$ & $\begin{array}{l}\text { Greater investment needed to reconstitute the agricultural system. } \\
\text { Smaller pool of experienced farmers, workers, processors or } \\
\text { traders. }\end{array}$ \\
\hline Livelihoods & $\begin{array}{l}\text { Changed livelihood composition (and possible loss of diversity). Depending on the } \\
\text { availability and nature of other options can result in a decrease or an increase in } \\
\text { vulnerability. }\end{array}$ & $\begin{array}{l}\text { Decline in rurality and agriculture as the basis for definition of such } \\
\text { (and programmes orientated towards this). }\end{array}$ \\
\hline \multicolumn{3}{|c|}{ 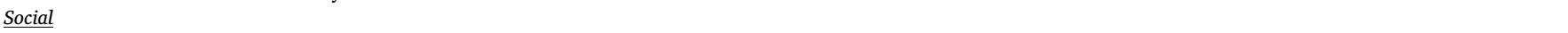 } \\
\hline Social relations & $\begin{array}{l}\text { Changed social relations as the neighbourliness associated with joint assistance with } \\
\text { ploughing and cropping will be lost. Within a household new roles will need to } \\
\text { emerge as agrarian roles fall away. }\end{array}$ & $\begin{array}{l}\text { The role of migrants to provide remittances for farming will } \\
\text { change. }\end{array}$ \\
\hline Community networks & $\begin{array}{l}\text { Networks developed around farming will weaken. Traditional observances based on } \\
\text { farming (e.g. harvest celebrations) will fade. }\end{array}$ & \\
\hline Crime & Perceived fear of encroached fields and deep gullies as sites for criminals to hide. & \\
\hline \multicolumn{3}{|c|}{ the } \\
\hline Identity & Changing agrarian identity. & \\
\hline Knowledge & Loss of cultural knowledge and values around the food production system. & Loss of pooled cultural knowledge and values. \\
\hline Tradition & $\begin{array}{l}\text { Loss of respect in being able to provide for household needs, reduced respect for } \\
\text { traditional ways of living. }\end{array}$ & Cultural homogenisation. \\
\hline \multicolumn{3}{|l|}{ Health } \\
\hline 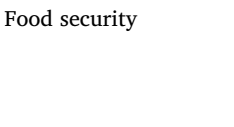 & $\begin{array}{l}\text { Food availability and stability potentially improved, quality and diversity of diet } \\
\text { potentially reduced. } \\
\text { Greater reliance on more intensive homegardens and/or store bought foods. Food } \\
\text { security likely to decrease if no household garden. }\end{array}$ & $\begin{array}{l}\text { Accelerated nutrition transition in rural areas (shift from nutrient- } \\
\text { dense to energy-dense and refined food). }\end{array}$ \\
\hline Health & & $\begin{array}{l}\text { Higher incidences of non-communicable diseases associated with } \\
\text { nutrition transition. Changes in rates of child stunting. }\end{array}$ \\
\hline
\end{tabular}

Africa, few people find local employment or casual work opportunities. Unless people are able to establish their own income generating activities, the partial or full disengagement from cropping will increase the number of unemployed and dependence on state welfare.

The decrease in or lack of field cultivation could also free up, for other investments, whatever cash was spent on agricultural inputs, such as fertilisers, seeds, pesticides, ploughing or labour. However, increased reliance on purchased food is likely to command much of the newly 'freed' cash, and indeed, many households may have less disposable income because of the higher costs of purchased foods. Similarly, at a regional scale, the reduction in the number of households that purchase agricultural inputs will affect the market chains and employment associated with such inputs.

The longer-term effects of a decline in cropping are likely to include a degeneration of agricultural knowledge and skills. Many of the elderly, for example, lament that the youth are not interested in

Table 3

Implications of a decline in the area used for field cultivation for species composition, ecological structure and ecological processes.

\begin{tabular}{|c|c|c|}
\hline Implication & Local & Regional/National \\
\hline \multicolumn{3}{|l|}{ Species composition } \\
\hline Biodiversity & $\begin{array}{l}\text { Increase in species richness and abundance, increasing resilience. } \\
\text { Enhanced availability of wild plant and animal resources. } \\
\text { Loss of agro-biodiversity (seed varieties \& species). }\end{array}$ & Increase in abundance as species move into abandoned land. \\
\hline $\begin{array}{l}\text { Encroacher \& invasive } \\
\text { species }\end{array}$ & $\begin{array}{l}\text { Greater niche for invasion of habitat transforming or encroaching invasive } \\
\text { species, negatively affecting native species. }\end{array}$ & $\begin{array}{l}\text { Greater coverage of undesirable species, requiring increased costs } \\
\text { for control. New invasion sources. }\end{array}$ \\
\hline Human wildlife interactions & $\begin{array}{l}\text { Increase in natural habitat increases prospects for conflict with dangerous and } \\
\text { crop raiding species. } \\
\text { Increased opportunity for bushmeat species. }\end{array}$ & $\begin{array}{l}\text { Increased 'natural' habitats will support greater prey populations, } \\
\text { which potentially will support greater predator populations } \\
\text { (cascading). }\end{array}$ \\
\hline \multicolumn{3}{|c|}{ - } \\
\hline Habitat connectivity & $\begin{array}{l}\text { Increased connectivity between natural habitats, increases resilience of system } \\
\text { to disturbance. }\end{array}$ & Greater area available for species migration. \\
\hline \multicolumn{3}{|l|}{ Ecological processes } \\
\hline Fire & Changes in fire frequency and intensity with plant succession. & Altered fire related and greenhouse gas emissions and albedo. \\
\hline Carbon sequestration & Increased above and belowground carbon sequestration. & $\begin{array}{l}\text { Contribute to national carbon budget at lower costs than active } \\
\text { planting/restoration. }\end{array}$ \\
\hline Erosion \& degradation & $\begin{array}{l}\text { Old farms prone to soil erosion and land degradation, however complex } \\
\text { dynamics and context specific. If significant can arrest natural revegetation. }\end{array}$ & $\begin{array}{l}\text { Likely change in sedimentation rates, hydrology, and } \\
\text { geomorphology of streams, rivers and dams. }\end{array}$ \\
\hline Forage production & $\begin{array}{l}\text { Initial increase in grass cover, and thus forage for grazers. Decrease in grass } \\
\text { cover on older fields will change the quantity and quality of grazing; potential } \\
\text { increase in browse. }\end{array}$ & Potentially slightly higher national herd of cattle and goats. \\
\hline
\end{tabular}


agriculture (Shackleton and Luckert, 2015; Hebinck et al., 2018). As the elderly retire from farming the knowledge they have gleaned and developed over decades about the local environments and soils, crop varieties and systems will be less accessible for those who may opt to take up cultivation sometime in the future. Additionally, those who continue to crop will have a smaller pool of compatriots whom they can consult on how to cope when they encounter difficulties or innovations.

The net effect of these economic changes for livelihoods will be highly variable both within and between communities. However, it is likely that the vulnerability for some households will increase. Such an adverse outcome is unattractive, as many rural households in the communal areas of South Africa are already extremely vulnerable (Shackleton and Shackleton, 2012; Shackleton and Luckert, 2015).

\subsubsection{Social}

Although it is clear that changes in household productive activities and deployment of labour will have social implications it is difficult to generalise. The social consequences will also be different for different role-players, such as women, the youth and the elderly. Some farmers look down on those who have stopped farming (Shackleton et al., 2013) while some of the youth do the opposite, i.e. they regard farming as the domain of the poor or unsophisticated. Moreover, the implications for social relations and community networks will also be shaped by the history of engagement with state interventions in land tenure and use, as well as the socioeconomic significance of land (e.g. forced removals, betterment schemes).

It can be expected that there will be some change in social relations, especially with respect to family and community level activities associated with agriculture. For example, there will be a reduced need for intra- and inter-household cooperation around ploughing and harvesting, which are typically regarded as very social processes (Fay, 2009). At an extreme, this may mean lower abilities to call on mutual assistance among neighbours and perhaps increase divisions when conflicts arise (such as when cattle raiding of a neighbour's crop occurs). Many rural villagers also dislike the loss of fields because the deactivated fields may become encroached by woody plants, which they fear will become hiding places for criminals (Fox, 2005; Shackleton et al., 2013).

\subsubsection{Cultural}

The majority of households in the communal areas of South Africa have had a long history of some engagement in field cropping and oral histories depict communities that identify as farming communities. Community elders recall times when most, if not all, staple food requirements were produced by the households, and supplemented to a small degree by purchases made possible with cash remitted by kin in large urban centres. However, the possibility of being able to feed the entire household from field produce declined with the advance of apartheid policies and forced resettlements, which decreased the land available per family. Betterment/villagisation schemes also relocated fields far from homesteads which resulted in increased levels of poverty and vulnerability. Nonetheless, an agrarian culture endures, and is firmly embedded in local identity. In the Eastern Cape, for example, a Xhosa landscape is regarded as one in which the land is productive and 'used' (read: cropped), interspersed with natural vegetation and grazing lands (Fox, 2005). For many households, growing something, either in fields or homegardens, is described as being part of their identity (Trefry et al., 2014; Shackleton and Hebinck, 2018). Consequently, a demise in the proportion of households engaged in cropping will challenge the very essence of local identity; yet what it may be replaced with is uncertain.

\subsubsection{Health}

It is well documented that the general diet of rural households in South Africa is dominated by starchy staples (mostly maize) and limited proteins and dietary diversity (Shisana et al., 2014). Even though diets are relatively monotonous, indigenous and domesticated vegetables nurtured in fields and homegardens are core for providing vital vitamins and micronutrients. Typically, maize fields are intercropped with pumpkins or butternut, beans, wild spinaches, and in the more subtropical areas, groundnuts. Some farmers may keep a section of their field for other vegetables such as cabbage, tomatoes, onions and spinach. After the maize harvest, winter vegetables may be planted in regions where water is available and winter temperatures not too harsh. Crop farming households have higher dietary diversity (Pereira et al., 2014; Chakona and Shackleton, 2017) and experience less hunger than those which do not, even though they may be more income poor (Rogan, 2018). Thus, loss of food diversity from deactivated fields must be compensated by homegardens or by purchased foods, otherwise individuals will become vulnerable to the ill-health effects resulting from a decline in dietary diversity, micronutrient intake and food security. This is to be avoided in a country where child wasting and stunting are already alarmingly high (Iversen et al., 2011; Shisana et al., 2014).

Even if cultivated crops are compensated through store purchases, there is evidence that different foods are purchased. South Africa is experiencing rapid dietary transitions to energy dense, fatty and refined foods (Bourne et al., 2002). This is currently most prevalent amongst the urban populations, but is also evident in rural areas as home produce declines and supermarkets penetrate into rural areas. Given sufficient disposable income to afford store bought foods, household food stability and security is likely to improve, but at the community level so too will the incidence of non-communicable diseases associated with diets rich in calories and refined foods (Bourne et al., 2002).

\subsection{Ecological consequences and implications of a decline in area under fields}

\subsubsection{Species composition}

The reduction in area of cultivated fields has significant implications for biodiversity, as well as the interaction between species. An increase in habitat availability and connectivity facilitates species movement and allows dispersal of animals such as small mammals and birds (Hansson, 1987; Brooker et al., 1999). This increases plant species richness and abundance in the old field site (Njwaxu, 2018), increasing the resilience of the system against disturbance. However, species that favour open habitats or field margins are likely to decline. This may also have implications for what species are available and favoured by local communities. For example, thatch grass and useful herbaceous species such a wild vegetables, which are common in active and recently abandoned fields, decline with increasing woody plant cover (Njwaxu, 2018). Thus, species compositional changes may result in a decrease or increase in use by different social groups.

A recently-deactivated field may also be prone to colonisation by invasive or encroacher species such as Lantana camara (Mack and Smith, 2011). This species has been reported as a pioneer in old fields on the Wild Coast, South Africa (Shackleton et al., 2013), where its increasing presence is associated with suppression of the density and species richness of recruits of indigenous forest species (Jevon and Shackleton, 2015). Because of this, the process of forest succession may be inhibited.

An increase in natural habitat and an increase in biodiversity in close proximity to human settlements also increases prospects for human-wildlife conflict. An increase in wildlife, particularly dangerous (snakes and jackals), or crop-raiding (monkeys, birds and rats) animals are perceived by villagers as undesirable (Shackleton et al., 2013; HerdHoare, 2018). However, bush thickening may also provide habitat for species considered as bushmeat, which is an important protein source for some communities (Shackleton et al., 2007). This again highlights the complex nature of this system, and how the change in species composition may benefit some, yet prove disadvantageous to others. There is also the perception that with fewer fields in the broader 
landscape that the incidence and severity of crop raiding is increased on the remaining fields (Herd-Hoare, 2018).

\subsubsection{Ecological structure}

When a deactivated field remains unused for a period, it starts to undergo natural plant succession, with consequences for habitat connectivity as well as heterogeneity. An increase in the natural vegetation may act as a corridor, thereby linking surrounding natural or seminatural habitats within the broader landuse matrix and improving overall connectivity (Fourie et al., 2015; Fahrig et al., 2011). However, in time tree and shrub encroachment may decrease open ground habitat and reduce heterogeneity in the landscape (Laiolo et al., 2004). Any change in vegetation structure can have a considerable impact on vegetation characteristics as well as animal populations. Increases in heterogeneity immediately after field deactivation may increase diversity, particularly avifauna and invertebrates, attracting more bird species into the area. These changes, however, are context specific and will differ not only across landscapes but also change over time as the local and landscape balance of wooded to open areas varies.

\subsubsection{Ecological processes}

A decline in the area cultivated will affect various physical, chemical and biological actions or events that link organisms and their environment. These ecological processes include soil erosion and land degradation. The removal of mechanised agricultural practices, such as ploughing, increases the bulk density of the soil, potentially resulting in the development of surface crusts. The soil surface becomes less penetrable and with an increase in bare patches, sediment yield and runoff are likely to increase, resulting in soil erosion (Rodrigo-Comino et al., 2017). Although this is context-specific, a general loss in vegetation cover is commonly associated with an increase in soil erosion which enhances land degradation (Rodrigo-Comino et al., 2017). If erosion increases significantly immediately after field deactivation, establishment of vegetation will be hindered. However, if vegetation does establish then erosion may be reduced relative to the cultivated state, but will depend on the magnitude of post-deactivation pressures such as fire and herbivory.

Old, disused fields are commonly associated with an increase in plant biomass, including the initial woody pioneer species such as Vachellia karroo (Shackleton et al., 2013). The accumulation of woody species increases aboveground and belowground carbon stocks, contributing to carbon sequestration (Silver et al., 2000). Reforestation rates however, depend on the frequency and intensity of disturbance, as well as the duration of the pioneer stage.

The change in plant biomass associated with plant succession in deactivated fields may also affect, and be affected by, fire frequency and intensity over time. Initially fire frequency increases with the establishment of herbaceous plants and shrubs (Ferreira-Leite et al., 2016). Fire frequency is then likely to decrease with the establishment of larger fire-tolerant woody species (Archer et al., 2017). However, fire frequency is also influenced by local perceptions and management. For example, on the Wild Coast Dwesa communities were strongly proburning, but communities from Cweba were strongly opposed to burning, for reasons relating to local understandings of succession and species responses to fire (Kepe and Scoones, 1999).

As woody cover and tree density increases in the old fields, grass and herbaceous cover decreases (Shackleton et al., 2013). This reduces the quantity and quality of forage available for grazing livestock. However, the production of browse will increase until (and if) the site becomes dominated by taller individuals and species. If stocking densities of domestic browsers such as goats are high, it may be possible to retard the rate of woody plant encroachment and establishment (Trollope et al., 1989).

\section{Conclusions}

The communal areas of South Africa are home to millions of people and represent a vital resource used to supply various livelihood needs. National policies typically characterise rural communities as agrarian and consequently current agricultural policy envisages commercial producers providing for formal markets. However, the reality is that most rural dwellers are not full-time farmers and small-scale agriculture or even gardening is simply part of a diverse livelihood portfolio. While many people do cultivate, evidence indicates that the number of households engaged in field cropping is declining and the area of land under field cropping is diminishing in many parts of the communal lands of South Africa, despite pro-agricultural policies nationally. Given the widespread nature of this phenomenon and the range of potential social, economic and ecological implications, we argue that it requires greater research attention and policy acknowledgement and realism.

Whilst advocating for research attention and policy acknowledgement and realism we also caution that research and policy responses need to be undertaken at the appropriate spatial and temporal scales. This requires that large-scale, remote sensing approaches be embedded in, rather than be a substitute for, ethnographic and livelihoods research on site, and that the approach be cognisant of and sensitive to longer-term dynamics and histories. For example, distinguishing corporate or government projects from local landuse changes using aerial imagery, which may depict an increase in areas under cultivation in communal areas, needs knowledge from the ground, and both need longer-term analyses.

In a similar vein, none of the studies to date have disaggregated the household or village data to understand if some social groups are involved in field deactivation more than others, and if so why. For example, is it mostly the elderly, those with limited labour, those whose fields are far away, female or male-headed households, those receiving social grants or various context-specific combinations of these? Additionally, which actors are most affected by the local level implications of field deactivation? Is it those who have withdrawn from small-scale cropping, their families, agricultural supply companies or local institutions? Understanding these aspects provides the foundation for more targeted responses by local and higher level institutions.

In accepting that there is a clear and long-term process of decline in the area of land under active fields in many regions under communal tenure in South Africa, but in some places sometimes punctuated with periods of reactivation, it is important that researchers, planners, local and traditional authorities and policy makers ask themselves what this means for livelihoods, economies and the land that used to be under fields. In terms of the last, the length of time since deactivation is crucial for both the likelihood of locally driven reactivation and the nature of other uses and benefit flows that the former cultivated areas might yield. The longer the period, the less likely will be the possibility for reactivation because many will have turned to other livelihood strategies. Also, agricultural knowledge and experience will have declined and the greater will be the labour and economic costs required to clear long deactivated fields of increasing densities of invasive plants or trees and shrubs.

In urging for local level studies and understanding, it is also necessary to have cross-site comparisons that foster nuanced disaggregation of why the processes, patterns and implications vary between sites. Only in understanding the variation can grounded and scale-relevant, responsive policies or interventions be considered. However, any policy responses or local level interventions must also recognise that land means more than just cropping and that rural livelihoods are more than just about producing food for home consumption or a marketable surplus. Land provides a variety of tangible (e.g. food, medicinal plants, grazing, water) and less tangible (e.g. identity, culture, spirituality, recreation, sense of place) benefit flows to rural households, communities and the nation; it is a multifunctional asset. Consequently, promoting only one or two benefit flows, such as field cropping, can 
impinge on the quality or magnitude of the others. Similarly, rural livelihoods are diverse, complex and adaptive, based on use of the land for multiple functions alongside non-land-based activities. Activation or deactivation of fields is an embodiment of the dynamic and adaptive nature of rural livelihoods.

\section{Acknowledgements}

The writing of this paper was made possible by funding from the South African Research Chairs Initiative of the Dept of Science and Technology and the National Research Foundation of South Africa. Any opinion, finding, conclusion or recommendation expressed in this material is that of the authors and the NRF does not accept any liability in this regard.

\section{References}

Aliber, M., 2015. Household-level food insecurity and agriculture in South Africa. In: Fukuda-Parr, S., Taylor, V. (Eds.), Food Security in South Africa: Human Rights and Entitlement Perspectives. UCT Press, Claremont, pp. 167-189.

Aliber, M., Cousins, B., 2013. Livelihoods after land reform in South Africa. J. Agrar. Change 13 (1), 140-165.

Aliber, M., Hall, R., 2012. Support for smallholder farmers in South Africa: challenges of scale and strategy. Dev. South. Afr. 29, 548-562.

Andrew, M., Fox, R.C., 2004. Undercultivation' and intensification in the Transkei: a case study of historical changes in the use of arable land in Nompa, Shixini. Dev. South. Afr. 21, 687-706.

Archer, S.R., Andersen, E.M., Predick, K.I., Schwinning, S., Steidl, R.J., Woods, S.R., 2017. Woody plant encroachment: causes and consequences. In: Briske, D. (Ed.), Rangeland Systems, https://doi.org/10.1007/978-3-319-46709-2_2. Springer, Cham.

Beilin, R., Lindborg, R., Stenseke, M., Pereira, H.M., Llausàs, A., Slätmo, E., Cerqueira, Y., Navarro, L., Rodrigues, P., Reichelt, N., Munro, N., Queiroz, C., 2014. Analysing how drivers of agricultural land abandonment affect biodiversity and cultural landscapes using case studies from Scandinavia, Iberia and Oceania. Land Use Policy 36, 60-72. https://doi.org/10.1016/j.landusepol.2013.07.003.

Benayas, M.R., Martins, A., Nicolau, M., Schulz, J.J., 2007. Abandonment of agricultural land: an overview of drivers and consequences. AB Rev. Perspect. Agric. Vet. Sci. Nutr. Nat. Resour. 2https://doi.org/10.1079/PAVSNNR20072057. 057.

Blair, D., Shackleton, C.M., Mograbi, P.J., 2018. Cropland abandonment in South African smallholder communal lands: land cover change (1950-2010) and farmer perceptions of contributing factors. Land 7, 121. https://doi.org/10.3390/land7040121.

Bourne, L.T., Lambert, E.V., Steyn, K., 2002. Where does the black population of South Africa stand on the nutrition transition? Public Health Nutr. 5, 157-162.

Brooker, L., Brooker, M., Cale, P., 1999. Animal dispersal in fragmented habitat: measuring habitat connectivity, corridor use, and dispersal mortality. Conserv. Ecol. [Online] 3 (1), 4. Available from the Internet. URL: http://www.consecol.org/vol3/ iss $1 /$ art $4 /$.

Brown, K., Ainslie, A., Beinart, W., 2013. Animal disease and the limits of local knowledge: dealing with ticks and tick-borne diseases in South Africa. J. R. Anthropol. Inst. 19, 319-337.

Bryceson, D.F., 1996. Deagrarianization and rural employment in sub-Saharan Africa. World Dev. 24, 97-111. https://doi.org/10.1016/0305-750X(95)00119-W.

Burgoyne, C., Kelso, C., Ahmed, F., 2016. Human activity and vegetation change around Mkuze Game Reserve, South Africa. South Afr. Geogr. J. 98, 217-234. https://doi. org/10.1080/03736245.2015.1028978.

Chakona, G., Shackleton, C.M., 2017. Minimum dietary diversity for women of indicate micronutrient adequacy and food insecurity status in South African towns. Nutrients 9https://doi.org/10.3390/nu9080812. 812 online.

Connor, T., Mtwana, N., 2018. Vestige garden production and deagrarianization in three villages in the Eastern Cape, South Africa. South Afr. Geogr. J. 100, 82-103. https:// doi.org/10.1080/03736245.2017.1301268.

Cousins, B., 2014. What is a "smallholder Farmer" in South Africa Today? In Opportunities, Constraints and Innovative Approaches in Small-Scale Agriculture in South Africa. Goedgedacht, Western Cape: C3 Initiative on Strategies to Overcome Poverty and Inequality.

Cousins, B., Chikazunga, D., 2013. Defining smallholder farmers in South Africa. Supporting Smallholders into Commercial Agriculture: a Social Dialogue and Learning Project. Proceedings of the First Innovation Lab. Southern Africa Food Lab (SAFL) and the Institute for Poverty, Land and Agrarian Studies (PLAAS). https:// www.plaas.org.za/sites/default/files/publications-pdf/SSCA\%20Report\%20on \%20first\%20Innovation\%20Lab\%20-\%2019Sept2013.pdf.

Cramer, V.A., Hobbs, R.J., Standish, R.J., 2008. What's new about old fields? Land abandonment and ecosystem assembly. Trends Ecol. Evol. 23, 104-112. https://doi. org/10.1016/j.tree.2007.10.005.

De Klerk, H., 2007. The Mutual Embodiment of Landscape and Livelihoods: an Environmental History of Nqabara. MSc Thesis. Rhodes University, Grahamstown $192 \mathrm{pp}$.

de la Hey, M., Beinart, W., 2017. Why have South African smallholders largely abandoned arable production in fields? A case study. J. South. Afr. Stud. 43, 753-770. https:// doi.org/10.1080/03057070.2016.1265336.
Department of Agriculture Forestry \& Fisheries, 2002. Integrated Food Security Policy. DAFF, South Africa, Pretoria.

Department of Agriculture Forestry Forestry and Fisheries, 2015. DAFF Strategic Plan 2015-16 to /2019/20. Pretoria.

Fahrig, L., Baudry, J., Brotons, L., Burel, F.G., Crist, T.O., Fuller, R.J., Sirami, C., Siriwardena, G.M., Martin, J.-L., 2011. Functional landscape heterogeneity and animal biodiversity in agri-cultural landscapes. Ecol. Lett. 14, 101-112.

Fay, D., 2003. "The Trust is Over! We Want to Plough!": Land, Livelihoods and Resettlement in South Africa's Transkei. Ph.D. Thesis. Boston University, Boston.

Fay, D., 2009. Land tenure, land use, and land reform at Dwesa-Cwebe, South Africa: local transformations and the limits of the state. World Dev. 37, 1424-1433. https://doi. org/10.1016/j.worlddev.2008.08.012.

Fay, D., 2013. Cultivators in action, Siyazondla inaction? Trends and potential in homestead cultivation in rural Mbhashe Municipality. In: Hebinck, P., Cousins, B. (Eds.), In the Shadow of Policy. Everyday Practices in South Africa's Land and Agrarian Reform. Witwatersrand University Press, Johannesburg, pp. 247-262.

Fay, D.A., 2015. Keeping land for their children' : generation, migration and land in South Africa's Transkei. J. South. Afr. Stud. 41, 1083-1097.

Fay, D., Palmer, R., 2002. Poverty and differentiation at Dwesa-Cwebe. In: Palmer, R., Timmermans, H., Fay, D. (Eds.), From Conflict to Negotiation: Nature-Based Development on South Africa's Wild Coast. Human Sciences Research Council, Pretoria, pp. 146-172.

Ferreira-Leite, F., Bento-Gonçalves, A., Vieira, A., Nunes, A., Lourenço, L., 2016. Incidence and recurrence of large forest fires in mainland Portugal. Nat. Hazards 84, 1035-1053.

Fourie, L., Rouget, M., Lötter, M., 2015. Landscape connectivity of the grassland biome in Mpumalanga, South Africa. Austral Ecol. 40, 67-76.

Fox, H., 2005. The Role of Anthropogenic Disturbance in the Creation of a Socio-ecological Landscape. Masters Thesis. Rhodes University, Grahamstown.

Giannecchini, M., Twine, W., Vogel, C., 2007. Land-cover change and human-environment interactions in a rural cultural landscape in South Africa. Geogr. J. 173, $26-42$.

Gouws, A., 2018. A Spatio-temporal, Landscape Perspective on Acacia dealbata Invasions and Broader Land-use and Cover Changes in the Northern Eastern Cape, South Africa. Masters Thesis. Rhodes University, Grahamstown 138 pp.

Greenberg, S., 2013. The Disjunctures of Land and Agricultural Reform in South Africa: Implications for the Agri-food System. PLAAS, University of Western Cape, Cape Town.

Gutura, P., Tanga, P.T., 2017. Income for the Whole Family': Exploring the contribution of social grants to rural household income in Ngqushwa Municipality, Eastern Cape province of South Africa. J. Soc. Sci. 50, 172-181.

Hansson, L., 1987. Dispersal routes of small mammals at an abandoned field in central Sweden. Ecography 10, 154-159.

Hebinck, P., Smith, L., 2007. A social history of Guquka and Koloni: settlement and resources. In: Hebinck, P., Lent, P.C. (Eds.), Livelihoods \& landscapes; the people of Guquka and Koloni and their resources. Brill Publishers, Leiden, pp. 91-120.

Hebinck, P., van Averbeke, W., 2007. Rural transformation in the Eastern Cape. In: Hebinck, P., Lent, P. (Eds.), Livelihoods and Landscape: the People of Guquka and Koloni and Their Resources. Brill Publishers, Leiden, pp. 33-66.

Hebinck, P., Mtati, N., Shackleton, C., 2018. More than just fields: reframing deagrarianisation in landscapes and livelihoods. J. Rural Stud. 61, 323-334. https://doi.org/ 10.1016/j.jrurstud.2018.01.004.

Hebinck, P., Cousins, B. (Eds.), 2013. In the Shadow of Policy. Everyday Practices in South Africa's Land and Agrarian Reform. Wits University Press, Johannesburg.

Hebinck, P., Lent, P. (Eds.), 2007. Livelihoods and Landscape: the People of Guquka and Koloni and Their Resources. Brill Publishers, Leiden.

Herd-Hoare, 2018. The Relative Role of Ecosystem Services and Disservices in Rural Livelihoods in the Eastern Cape Province, South Africa. MSc Thesis. Rhodes University, Grahamstown 160 pp.

IFAD, 2009. An Unrealized Potential: Increasing Agricultural Productivity in Sub-saharan Africa. Progress in Eastern \& Southern Africa, 11, March 2009. https://www.ifad. org/newsletter/pf/11.htm\#2.

Iversen, P.O., du Plessis, L., Marais, D., Morseth, M., Adolfsen Høisæther, E., Herselman, M., 2011. Nutritional health of young children in South Africa over the first 16 years of democracy. South Afr. J. Child Health 5, 72-77.

Jevon, T., Shackleton, C.M., 2015. Integrating local knowledge and forest surveys to assess Lantana camara impacts on indigenous species recruitment in Mazeppa Bay, South Africa. Hum. Ecol. 43, 247-254.

Jewitt, D., Goodman, P.S., Erasmus, B.F.N., O'Connor, T.G., Witkowski, E.T.F., 2015. Systematic land-cover change in KwaZulu-Natal, South Africa: implications for biodiversity. S. Afr. J. Sci. 111 (9/10). https://doi.org/10.17159/ sajs.2015/20150019. Art. \#2015-0019.

Kepe, T., Scoones, I., 1999. Creating grasslands: social institutions and environmental change in Mkambati area, South Africa. Hum. Ecol. 27, 29-53.

Laiolo, P., Dondero, F., Ciliento, E., Rolando, A., 2004. Consequences of pastoral abandonment for the structure and diversity of alpine avifauna. J. Appl. Ecol. 41, 294-304.

Lambin, E.F., Turner, B.L., Geist, H.J., Agbola, S.B., Angelsen, A., Bruce, J.W., Coomes, O.T., Dirzo, R., Fischer, G., Folke, C., George, P.S., Homewood, K., Imbernon, J., Leemans, R., Li, X., Moran, E.F., Mortimore, M., Ramakrishnan, P.S., Richards, J.F., Skanes, H., Steffen, W., Stone, G.D., Svedin, U., Veldkamp, T.A., Vogel, C., Xu, J., 2001. The causes of land-use and land-cover change : moving beyond the myths. Glob. Environ. Chang. Part A 11, 261-269.

Lent, P.C., Mupakati, G., 2007. The view from above: a history of land use in Guquka and Koloni, 1938-1996. In: Hebinck, P., Lent, P.C. (Eds.), Livelihoods and Landscape: the People of Guquka and Koloni and Their Resources. Brill, Leiden, pp. 165-180.

Li, S., Li, X., 2017. Global understanding of farmland abandonment: a review and 
prospects. Int. J. Geogr. Inf. Sci. 27, 1123-1150. https://doi.org/10.1007/s11442017-1426-0.

Mack, R., Smith, M., 2011. Invasive plants as catalysts for the spread of human parasites. NeoBiota 9, 13-29. https://doi.org/10.3897/neobiota.9.1156.

Manyevere, A., Muchaonyerwa, P., 2014. Farmers' perspectives with regard to crop production: an analysis of Nkonkobe Municipality, South Africa. J. Agric. Rural Dev. Trop. Subtrop. 115, 41-53.

Masubelele, M., Hoffman, M.T., Bond, W.J., 2015. Biome stability and long-term vegetation change in the semi-arid, south-eastern interior of South Africa: a synthesis of repeat photo-monitoring studies. South Afr. J. Bot. 101, 139-147.

Masunungure, C., Shackleton, S.E., 2018. Exploring long-term livelihood and landscape change in two semi-arid sites in southern Africa: drivers and consequences for social-ecological vulnerability. Land 7, 50. https://doi.org/10.3390/land7020050.

Matsika, R., 2012. The Spatio-temporal Dynamics of Woody Biomass Supply and Demand in Response to Human Utilisation in an African Savanna Woodland. PhD Thesis. University of the Witwatersrand, Johannesburg $267 \mathrm{pp}$.

McCusker, B., 2004. Land use and cover change as an indicator of transformation on recently redistributed farms in Limpopo Province, South Africa. Hum. Ecol. 32, 49-75.

Meyfroidt, P., Lambin, E.F., Erb, K.H., Hertel, T.W., 2013. Globalization of land use: distant drivers of land change and geographic displacement of land use. Curr. Opin. Environ. Sustain. 5, 438-444. https://doi.org/10.1016/j.cosust.2013.04.003.

Munroe, D.K., van Berkel, D.B., Verburg, P.H., Olson, J.L., 2013. Alternative trajectories of land abandonment: causes, consequences and research challenges. Curr. Opin. Environ. Sustain. 5, 471-476. https://doi.org/10.1016/j.cosust.2013.06.010.

Ncube, N., Tanga, P.T., Bhumira, B., Ncube, N., Tanga, P.T., Bhumira, B., 2017. The impact of de-agrarianisation on the socio-economic well-being of rural inhabitants in South Africa. J. Hum. Ecol. 48, 399-406.

Njwaxu, A., 2018. Assessing the Abundance of Non-timber Forest Products in Relation to Forest Succession on the Wild Coast, South Africa. Masters Thesis. Rhodes University, Grahamstown.

Pereira, H.M., Navarro, L.M., 2015. Rewilding European Landscapes. Springer, Heidelberg.

Pereira, L.M., Cuneo, C.N., Twine, W.C., 2014. Food and cash: understanding the role of the retail sector in rural food security in South Africa. Food Secur. 6, 339-357. https://doi.org/10.1007/s12571-014-0349-1.

Pienaar, P.L., 2013. Typology of Smallholder Farming in South Africa's Former Homelands: Towards an Appropriate Classification System. Masters Thesis. Stellenbosch University, Stellenbosch.

Pointereau, P., Coulon, F., Girard, P., Lambotte, M., Stuczynski, T., Sánchez Ortega, V., Del Rio, A., 2008. Analysis of Farmland Abandonment and the Extent and Location of Agricultural Areas That Are Actually Abandoned or Are in Risk to Be Abandoned, JRC Scientific and Technical Reports. Italy. https://doi.org/10.13140/RG.2.1.2467.7849.

Ramankutty, N., Foley, J.A., 1999. Estimating historical changes in global land cover: croplands from 1700 to 1992. Global Biogeochem. Cycles 13, 997-1027. https://doi. org/10.1029/1999GB900046.

Republic of South Africa, 2012. National Development Plan, Vision 2030. Government Printer, Pretoria.

Rey Benayas, J., Martins, A., Nicolau, J.M., Schulz, J.J., 2007. Abandonment of agricultural land: an overview of drivers and consequences. CAB Rev. Perspect. Agric. Vet. Sci. Nutr. Nat. Resour. 2. https://doi.org/10.1079/PAVSNNR20072057.

Rodrigo-Comino, J., Martínez-Hernández, C., Iserloh, T., Cerdà, A., 2017. The contrasted impact of land abandonment on soil erosion in Mediterranean agriculture fields. Pedosphere. https://doi.org/10.1016/S1002-0160(17)60441-7.

Rogan, M., 2018. Food poverty, hunger and household production in rural Eastern Cape households. Dev. South. Afr. 35, 90-104. https://doi.org/10.1080/0376835X.2017. 1358602.

Rohde, R.F., Hoffman, M.T., 2008. One hundred years of separation: the historical ecology of a South African 'Coloured Reserve'. Africa 78, 189-222.

Samberg, L.H., Gerber, J.S., Ramankutty, N., Herrero, M., West, P.C., 2016. Subnational distribution of average farm size and smallholder contributions to global food production. Environ. Res. Lett. 11, 1-11. https://doi.org/10.1088/1748-9326/11/12/ 124010.

Shackleton, S.E., Hebinck, P., 2018. Through the `Thick and thin' of farming on the Wild Coast, South Africa. J. Rural Stud. 61, 277-289. https://doi.org/10.1016/j.jrurstud. 2018.01.012.

Shackleton, S.E., Luckert, M., 2015. Changing livelihoods and landscapes in the rural Eastern Cape, South Africa: past influences and future trajectories. Land 4, 1060-1089. https://doi.org/10.3390/land4041060.

Shackleton, S.E., Shackleton, C.M., 2012. Linking poverty, HIV/AIDS and climate change to human and ecosystem vulnerability in southern Africa: consequences for livelihoods, sustainable ecosystem management and development. Int. J. Sustain. Dev. World Ecol. 19, 275-286.

Shackleton, C.M., Shackleton, S.E., Cousins, B., 2001. The role of land-based strategies in rural livelihoods: the contribution of arable production, animal husbandry and natural resource harvesting in communal areas in South Africa. Dev. South. Afr. 18, 581-604. https://doi.org/10.1080/03768350120097441.

Shackleton, C.M., Timmermans, H.G., Nongwe, N., Hamer, N., Palmer, R., 2007. Directuse values of non-timber forest products from two areas on the Transkei Wild Coast. Agrekon 46, 113-134.

Shackleton, R., Shackleton, C., Shackleton, S., Gambiza, J., 2013. Deagrarianisation and forest revegetation in a biodiversity hotspot on the Wild Coast, South Africa. PLoS One 8, 1-12. https://doi.org/10.1371/journal.pone.0076939.

Shisana, O., Labadarios, D., Rehle, T., Simbayi, L., Zuma, K., Dhansay, A., Reddy, P., Parker, W., Hoosain, E., Naidoo, P., Hongoro, C., Mchiza, Z., Steyn, N.P., Dwane, N., Makoae, M., Maluleke, T., Ramlagan, S., Zungu, N., Evans, M.G., Jacobs, L., Faber, M., the SANHANES-1 Team, 2014. South African National Health and Nutrition Examination Survey (SANHANES-1): 2014 Edition. HSRC Press, Cape Town.

Silver, W.L., Ostertag, R., Lugo, A.E., 2000. The potential for carbon sequestration through reforestation of abandoned tropical agricultural and pasture lands. Restor. Ecol. 8, 394-407.

Stevens, N., Bond, W., Hoffman, M.T., Midgley, G., 2015. Change Is in the Air: Ecological Trends and Their Drivers in South Africa. South African Environmental Observation Network (SAEON), Pretoria. http://www.saeon.ac.za/Change $\% 20$ is $\% 20$ in $\% 20$ the \%20air WEB\%20VERSION.pdf.

Stickler, M.M., Shackleton, C.M., 2015. Local wood demand, land cover change and state of Albany Thicket of an urban commonage in the Eastern Cape, South Africa. Environ. Manage. 55, 411-422.

Swemmer, A.M., Mashele, M., Ndhlovu, P.D., 2018. Evidence for ecological sustainability of fuelwood harvesting at a rural village in South Africa. Reg. Environ. Change. https://doi.org/10.1007/s10113-018-1402-y.

Tavenner, K., 2016. A Feminist Political Ecology of Indigenous Vegetables in a South African Protected Area Community. PhD Thesis. Pennsylvania State University.

Timmermans, H.G., 2004. Rural livelihoods at Dwesa/Cwebe: poverty, development and natural resource use on the Wild Coast, South Africa. Unpublished MSc thesis, Environmental Science Department. Rhodes University, Grahamstown, pp. 188.

Trefry, A., Parkins, J., Cundill, G., 2014. Culture and food security: a case study of homestead food production in South Africa. Food Secur. 6, 555-565. https://doi.org/ 10.1007/s12571-014-0362-4.

Trollope, W.S., Hobson, F.O., Danckwerts, J.E., van Niekerk, J.P., 1989. Encroachment and control of undesirable plants. In: Danckwerts, J.E., Teague, W.R. (Eds.), Veld Management in the Eastern Cape. Department of Agriculture and Water Supply, Pretoria, pp. 73-89.

UNCTAD, 2015. Commodities and Development Report 2015: Smallholder Farmers and Sustainable Commodity Development. Geneva. . 